\title{
Don't Burn the Books, Read Them!*
}

\author{
AMANDA WATSON**
}

\begin{abstract}
Why do we still have books? To answer this question with views based not on the market trend, nor on the popular feeling that print is outdated and irrelevant, but on the American Bar Association's stated mission of Law Libraries to provide resources that enable legal education, ${ }^{1}$ this article reviews the potential benefits and determents of different types of legal sources using both print and online formats and discusses whether external pressures should outweigh these factors dependent on the audience.
\end{abstract}

\section{Contents}

Introduction

Benefits and Detriments

Preference

Performance

Time-consumption

Multi-tasking

Annotation

Eyestrain

Environmental Sustainability

Ease of Discovery

Ease of Delivery

Perception

Outside Factors

Budget

Space

Audience Consideration

Technology Gaps

Conclusion

* Many thanks to Dean Leonard Baynes for asking hard questions and always listening to the answers. Thanks also to my research librarian Robert Clark, my former teaching assistant and friend Jennifer Richards, and my editor and partner Elizabeth Bolles for constant help in all things.

** (C) Amanda Watson 2018. The author is Director, John M. O’Quinn Law Library and Assistant Professor, University of Houston Law Center, Houston, Texas.

${ }^{1}$ See, ABA Standards for Approval of Law Schools, Chapter 6, https://www.americanbar.org/content/dam/aba/publications/misc/legal_education/Standards/2017-2018ABAStandardsforApprovalofLawSchools/2017_2018_standards_chapter-6. authcheckdam.pdf 
Primary Sources

Secondary Sources

Textbooks and Study Aids

Answers

"There are worse crimes than burning books. One of them is not reading them."

\section{INTRODUCTION}

"Why do we have all these books?" Early in the Fall of my first year as Director of the O'Quinn Law Library at the University of Houston Law Center, my Dean asked me this question. He explained he had toured an alumna through the library from a local, large law firm, and they had posed the question to him.

The University of Houston Law Center holds just over 280,000 print volumes. ${ }^{3}$ While our neighbor's collection in Austin, the University of Texas Tarlton Law Library, dwarves ours with its over one million print volumes, ${ }^{4}$ our count is comparable to other academic law libraries in Texas. ${ }^{5}$ Yet, even small print collections like ours are often questioned as to their relevance or currency. ${ }^{6}$

Administrators tend to assume electronic resources are cheaper and superior for learning. ${ }^{7}$ Some legal decision makers have gone so far as to say law print collections are "going the way of the Walkman, Betamax players and 35-millimeter cameras." "What matters most to law schools? Going forward, it will not be law libraries," said former Law Library Director, law professor and digital media expert at the University of Buffalo School of Law, James Milles. ${ }^{9}$ Other factors are undoubtedly at play, but our physical collections are at the heart of this prediction. ${ }^{10}$

Indeed, conversion and use of digital sources has been a constant since the advent of personal computers in the 1990s. ${ }^{11}$ Barely one decade ago, the introduction of portable screen reading devices prompted an explosion of eBooks. ${ }^{12}$ eBook sales rose 354 percent in 2008 alone. ${ }^{13}$

Legal research mirrored these trends to a large extent. In 1973, the Mead Data Center introduced LEXIS, a digital service that provided some state and federal codes and cases. ${ }^{14}$ By the late 1970 s, robust discussions of online legal research were happening in the law library world. ${ }^{15}$ West Publishing introduced a product called InstaCite in the mid-1980s, which would eventually become KeyCite, now an integral part of the Westlaw platform. ${ }^{16}$ In 1980 ,

${ }^{2}$ Joseph Brodsky, Independent on Sunday, May 19, 1991. (Spoken on acceptance of US poet laureateship, Washington DC.)

${ }^{3}$ Report from ALLStar Benchmarking (on file with author). See http://www.nellco.org/page/allstar.

${ }^{4}$ University of Texas, Tarlton Law Library/The Joseph D. Jamail Center for Legal Research at http://catalog.utexas. edu/general-information/libraries-and-other-academic-resources/legal-research-tarlton-law-library/.

${ }^{5}$ Report from ALLStar Benchmarking (on file with author). See http://www.nellco.org/page/allstar.

${ }^{6}$ See, e.g., Ursula Gorham \& Paul T. Jaeger, The Law School Library or the Library at the Law School? How Lessons from Other Types of Libraries Can Inform the Evolution of the Academic Law Library in the Digital Age, 109 LAw LiBR. J. 51, 52, 2017 LaW LiBr. J. 2, ๆ 2.

${ }^{7}$ Sung Wook Ji et al., Print vs. Electronic Readings in College Courses: Cost-Efficiency and Perceived Learning, 21 J. High. Educ. 17, 17. (2014).

${ }^{8}$ M. P. McQueen, The Bookless Library, Am. Law., July 2015, at 64.

9 James G. Milles, Legal Education in Crisis, and Why Libraries Are Doomed, 106 Law LiBr. J. 507, 519, 2014 Law LiBR. J. 28,90 .

${ }^{10} \mathrm{Id}$. at 517, ๆ 34

${ }^{11}$ Naomi S. Baron et al., The Persistence of Print Among University Students: An Exploratory Study, 34 Telematics \& INFORMATICS 590, 590 (2017).

${ }^{12} \mathrm{Jim}$ Milliot, BEA 2013: The E-Book Boom Years, PuBLISHERs WeEKLY, https://www.publishersweekly.com/pw/by-topic/ industry-news/bea/article/57390-bea-2013-the-e-book-boom-years.html.

${ }^{13} I d$.

${ }^{14}$ LexisNexis, The LexisNexis Timeline, http://www.lexisnexis.com/anniversary/30th_timeline_fulltxt.pdf.

${ }^{15}$ See, e.g., Terry Appenzellar, "Online Information Retrieval for the Legal Profession" 70 LAW LIBR. J. 532 (1977).

${ }^{16}$ Nick Borger, Celebrating 20 Years of Excellence with KeyCite on Westlaw, https://legalsolutions.thomsonreuters.com/ law-products/westlaw-legal-research/insights/celebrating-20-years-of-excellence-with-keycite-on-westlaw. 
Mead Data Central (the then maker of Lexis) reported just below five million dollars in revenue. ${ }^{17}$ Electronic publishing represented only 3 percent of their holdings at that time, which included a large paper manufacturing business. ${ }^{18}$ After the e-boom, Reed Elsevier, current parent company to LexisNexis, reported the equivalent of 2.5 billion dollars in U.S. revenue. ${ }^{19}$ By 2008, Thomson Reuters, owner of Westlaw, reported 90 percent of its over 13 billion dollars in revenue were in electronic media. ${ }^{20}$

But even if digital media is the leader of the market does that mean it is or should be leader of our collections? In the past decade, law librarians have turned to digital collections because of factors like budget cuts and pricing, rather than relying on professional preference for learning impact. ${ }^{21}$ Librarian and lecturer Jeanne Holba Puacz quotes librarian and digital pioneer Kathy Niemeier, "[i]t is a "mistake...to assume the need for information is finite and that it can be fully satisfied in any single medium.' There are pros and cons to each format." 22 Since the advent of online legal research services, law libraries of all types have investigated and weighed the features of print and online sources. ${ }^{23}$ But research indicates that while digital is the market leader, it has not necessarily earned that position through intention, and as such may not be best for our students.

The ABA standards dictate a "law school shall maintain a law library that: provides support through expertise, resources, and services adequate to enable the law school to carry out its program of legal education, accomplish its mission, and support scholarship and research..."24

Why do we have all these books? I seek to answer this question based not on the market trend, nor on the popular feeling that print is outdated and irrelevant, but on the ABA's stated mission of Law Libraries to provide resources that enable legal education. This article will review the potential benefits and determents of different types of legal sources using both print and online formats. By diving into scientific study, many issues are revealed concerning digital and print media. Those issues are taken in turn below.

\section{Benefits AND Detriments}

\section{Preference}

Do students prefer electronic format? Dr. Diane Mizrachi from UCLA says "[c]ontrary to popular stereotype, surveys for more than a decade show that [students] consistently prefer reading their academic texts in print." 25 Even if it was somehow preferred, should we as librarians care about student preference? Students might not like to take required courses or have a grade scale that averages to a grade other than an A+, but we are certainly comfortable taking these decisions out of their hands. Why then should their perceived preference dictate our library holdings? It should certainly influence decision-making, but not dictate it. After all, "[h]umans in general are poor judges of how much they know." 26

${ }^{17}$ Mead Data Central, 1984 Annual Report 24 (1985).

${ }^{18} I d$. at 25 .

${ }^{19}$ Reed Elsevier, 2008 Annual Report 16 (2009).

20 Thomson Reuters, 2008 Annual Review, http://archive.annual-report.thomsonreuters.com/2008/revenue.htm.

${ }^{21}$ See, e.g., Bob Wharburton, Libraries Around the Country Under Budget Pressure, Libr. J., June 28, 2013, https://1.libraryjournal.com/2013/06/funding/libraries-around-the-country-under-budget-pressure.

${ }^{22}$ Jeanne Holba Puacz, Electronic vs. Print Reference Sources in Public Library Collections, 44 Reference Librarian 39, 50 (2005), quoting Kathy Niemeier, The Medium Must Match the Message, 6 Ref. Librarian 217, 223 (2009).

${ }^{23}$ See, e.g., Robert J. Munro et al., LEXIS vs. WESTLAW: An Analysis of Automated Education, 71 LAw LiBr. J. 471 (1978).

${ }^{24}$ Section on Legal Educ. And Admissions to the Bar, Am. Bar Ass'n, ABA Standards and Rules of Procedure for Approval of LaW Schools 2017-2018, at 39 (2017).

${ }^{25}$ Diane Mizrachi, Undergraduates' Academic Reading Format Preferences and Behaviors, 41 J. AcAD. LiBr. 301, 302 (2015).

${ }^{26}$ David B. Daniel \& William Douglas Woody, E-textbooks at What Cost? Performance and Use of Electronic v. Print Texts, 62 COMPUTERS \& Educ. 18, 18 (2013). 


\section{Performance}

Studies have shown generally that format of study materials and textbooks are not the driving factor in overall student performance on examinations. ${ }^{27}$ Drs. Daniel and Woody created a study where students read on various mediums and found study environment and overall student GPA to be more significant contributors to success than media. ${ }^{28}$ It is interesting to note, however, in a similar study by Drs. Ji, Michaels, and Waterman, where participants were given either print or electronic readings for a course, the students using print resources had a felt sense they performed better when using print. ${ }^{29}$

When studies focused on reading comprehension not just grade performance, lower comprehension of material has been found when it is presented in digital format. ${ }^{30}$ Drs. Mangen, Walgermo, and Brønnick, studied students' reading comprehension among formats, allowing them to refer back to the format assigned. "Subjects who read the texts on paper performed significantly better than subjects who read the texts on the computer screen." ${ }^{1}$ Document navigation may play a role in this, specifically negative effects of scrolling. ${ }^{32}$ Drs. Morineau, Blanche, Tobin, and Guéguen's study found that the media itself presents or obscures context clues that can help or hinder performance. ${ }^{33}$ In that study, students were presented with various texts and their performance was tested on multiple variables. ${ }^{34}$

A study consisting of an entire credit course based in either electronic or print format by Drs. Lauterman and Ackerman showed basic reading comprehension across formats may differ based on the information processing strategy at hand, superficial or deep understanding. ${ }^{35}$ They conclude "the natural learning process tends to be shallower on screen than on paper." 36 Drs. Baron, Calixte, and Havewala, measured student impressions about print and digital media, and found that with longer texts readers show a preference for print, while shorter texts show no reader preference between formats. ${ }^{37}$ Lauterman and Ackerman's study found " $60 \%$ of the participants stated that they would print the text for thorough learning." 38 Mizrachi's survey found "more respondents preferred scholarly monographs in print...electronic versions for conference proceedings." 39 In librarian Nancy Foasberg's qualitative study, students consistently recorded print as favorable for "long form and academic reading." 40 This type of association with "shallow" learning and reading on screen is consistent. ${ }^{41}$ Drs. Farinosi, Lim, and Roll, created a survey of students to determine their habits and preferences in uses of print and electronic reading formats. ${ }^{42} \mathrm{~A}$ student reported "[i]f the text is pleasant and short, the digital support is preferred. If the text requires strategic reading, such as papers, essays, books, the paper version is preferred." 43

Since performance isn't directly tied to either media, neither gets a win in this category, though print does edge out electronic for long format reading comprehension.

${ }^{27}$ Alexandre Porion et al., The Impact of Paper-based Versus Computerized Presentation on Text Comprehension and Memorization, 54 Computers Hum. Behav. 569, 573 (2016).

28 Daniel, supra note 25 , at 20.

$29 \mathrm{Ji}$, supra note 6 , at 23.

${ }^{30}$ Anne Mangen et al., Reading Linear Texts on Paper Versus Computer Screen: Effects on Reading Comprehension, 58 INT'L J. EduC'L ReS. 58, 65 (2013).

31 Ibid.

32 Ibid.

33 Thierry Morineau et al., The Emergence of the Contextual Role of the E-Book in Cognitive Processes Through an Ecological and Functional Analysis, 62 InT'L J. Human-Computer STUd. 329, 344 (2005).

${ }^{34}$ Ibid at 337.

${ }^{35}$ Tirza Lauterman \& Rakefat Ackerman, Overcoming Screen Inferiority in Learning and Calibration, 35 COMPUTERs HuM. BeHAV. 455, 460 (2014).

36 Ibid. at 461.

${ }^{37}$ Baron, supra note 10 , at 596.

38 Lauterman, supra note 34 , at 460.

39 Mizrachi, supra note 24 , at 302.

40 Nancy M. Foasberg, Student Reading Practices in Print and Electronic Media, 75 C. \& Res. LiBR. 705,719 (2014).

${ }^{41}$ See, e.g., Elizabeth Norman \& Bjarte Furnes, The Relationship Between Metacognitive Experiences and Learning: Is There a Difference Between Digital and Non-digital Study Media?, 54 Computers Hum. Behav. 301,303 (2016).

${ }^{4}$ Manuela Farinosi et al., Book or Screen, Pen or Keyboard? A Cross-cultural Sociological Analysis of Writing and reading Habits Basing on Germany, Italy and the UK, 33 Telematics \& Informatics 410, 410 (2016).

${ }^{43}$ Ibid. at 417. 


\section{Time Consumption}

Studies on time consumption are more conclusive. Students reading electronic media in the Daniel study took longer to complete readings than peers reading the same material in print. ${ }^{44}$ This is a clear win for print media. These results held true whether reading in a formal study space or casually at home. ${ }^{45}$

\section{Multi-Tasking}

A student in the Baron study reported "reading in hardcopy makes me focus more on what I am reading." 46 The ability to concentrate is often discussed in studies about digital formats. In Baron's study, 91.8 percent of participants self-identified print as allowing easier concentration. ${ }^{47}$ Farinosi concluded that because print has no added features, it requests the sole focus of the reader. ${ }^{48}$ One of the participants noted "[a] paper book really allows you to focus on the task in hand; there is no temptation to quickly check emails, etc." 49

These self-identifications are borne out by the Daniel study, showing participants reading in digital formats were more likely to respond to digital messages or use social media than those using print formats. ${ }^{50}$ Again, one of Farinosi's participants commented "reading on screen creates a disconnection." 51

In Mangen's study, even features intended to increase understanding were shown to hinder performance. ${ }^{52}$ A study designed to test cognitive effects of hypertext features by Drs. DeStefano and LeFevre showed hyperlinks in texts increase mental load and processing, which limits reading performance. ${ }^{53}$ These studies show a win for print media when multi-tasking is to be avoided.

\section{Annotation}

Mizrachi found "[h]ighlighting and annotating are behaviors that reflect active engagement with a text in an effort to learn and retain information." ${ }^{4}$ Baron concludes print is preferred by most, noted to be easier to annotate or underline. ${ }^{55}$ Drs. Norman and Furnes ran a study varying exposure to print and various electronic media. ${ }^{56}$ There is some evidence from this study that note-taking improves learning. ${ }^{57}$ The study showed that participants annotate print more often than those who use electronic reading. ${ }^{58}$

Along with making marks, Farinosi noted indicators of where users are in a text give print an advantage. ${ }^{59}$ Actually understanding their progress makes a difference cognitively and helps participants retain information. ${ }^{60}$ Annotation is another win for print reading.

${ }^{44}$ Daniel, supra note 25 , at 20.

${ }^{45}$ Daniel, supra note 25, at 22.

${ }^{46}$ Baron, supra note 10 , at 598.

${ }^{47}$ Ibid. at 596.

${ }^{48}$ Farinosi, supra note 41 , at 417.

${ }^{49}$ Ibid.

${ }^{50}$ Daniel, supra note 25, at 22.

${ }^{51}$ Farinosi, supra note 41 , at 418.

52 Mangen, supra note 29, at 61.

${ }^{53}$ Diana DeStefano \& Jo-Anne LeFevre, Cognitive Load in Hypertext Reading: A Review, 23 Computers Hum. Behav. 1616, 1617 (2007).

${ }^{54}$ Mizrachi, supra note 24, at 304.

${ }_{55}^{55}$ Baron, supra note 10, at 592.

${ }^{56}$ Norman, supra note 40 , at 304.

${ }^{57} \mathrm{Ibid}$. at 307.

${ }^{58}$ Ibid.

${ }^{59}$ Farinosi, supra note 41, at 417.

${ }^{60}$ Ibid. 


\section{Eyestrain}

"[N]ot good for the eyes," said one participant in Baron's study about using digital screens. ${ }^{61}$ In fact, 45.5 percent of participants surveyed in Baron's study chose issues around eyestrain as the least liked feature of digital reading among dozens of physical, emotional, cognitive, and convenience features. ${ }^{62}$ Mangen found that " $[\mathrm{c}]$ haracteristics of the computer screen (refresh rate, high levels of contrast and fluctuating luminance) interfere with cognitive processing for long-term memory." 63 In addition to other negative factors, participants in the Wästlund study self-reported "higher levels of stress and fatigue than those who read paper." 64 Again, a win is scored for print.

\section{Environmental Sustainability}

One interesting facet of studying print and digital media, is that often students may prefer digital media but ultimately choose to print out the media to read as noted in the Ji study. ${ }^{65}$ More often than actual books, this is cited by students to be irresponsible environmentally. ${ }^{66}$ One of Baron's participants says "[w]hile I prefer reading things in Hardcopy, I can't bring myself to print out online material simply for the environmental considerations." 67 This is a complicated finding, indicating a possible win for electronic reading as to sustainability, but not a clear loss for print as long as the student was using a book and not printing out a digital copy.

\section{Ease of Discovery}

This is most certainly a win for electronic formats. ${ }^{68}$ "By the 1960 s, there was much talk in the legal profession about the geometric rate of increase in the amount of material a lawyer had to scan to do a comprehensive job of legal research." 69

"[S]tudents and academic researchers often turn to Google Scholar to conduct their initial scholarly searches, instead of library catalogs and...databases" because of what one scholar calls "Google fluency."70 This preference persists among legal researchers. ${ }^{71}$ LexisAdvance and WestlawNext provide Google-like electronic databases for lawyers. ${ }^{72}$ Library catalogs and other databases have made attempts to come more into Google-like discovery, but have not been able to find the right mix. For instance, at the University of Houston Law Center, a recent survey of students revealed that 47.75 percent of students never used the online catalog, while the same students took time to write comments praising the areas of the print collection that were arranged outside traditional call number schemes. ${ }^{73}$

\section{Ease of Delivery}

Print takes another loss here, as studies show lack of convenience in getting print as a determent of the format. ${ }^{74}$ The same studies show access to materials and convenience among the highest attributes of digital

\footnotetext{
${ }^{61}$ Baron, supra note 10 , at 598.

62 Ibid. at 601.

${ }^{63}$ Mangen, supra note 29, at 62.

${ }^{64}$ Porion, supra note 26, at 570.

$65 \mathrm{Ji}$, supra note 6 , at 17.

${ }^{66}$ Baron, supra note 10 , at 592.

${ }^{67}$ Baron, supra note 10 , at 599.

68 Ibid. at 592.

${ }^{69}$ William G. Harrington, A Brief History of Computer-Assisted Legal Research, 77 LAW LiBR. J. 543, 544 (1985).

${ }^{70}$ Taryn Marks \& Avery Le, Increasing Article Findability Online: The Four Cs of Search Engine Optimization, 109 LAw LiBr. J. 83, 85, 2017 LAw LiBR. J. 4 at 7.

71 Ibid.

72 Ibid. at 86 व 11.

${ }^{73}$ University of Houston Law Center Library Student Survey (on file with author).

74 Baron, supra note 10 , at 597.
} 
formats. ${ }^{75}$ Students show a great preference for digital materials that are easy to download, choosing a PDF option when offered. ${ }^{76}$

\section{Perception}

In a study to measure e-book use across academic disciplines, one student wrote "end of print books = end of civilization." "77 As noted above in the Ji study, students perceive their own understanding to be higher when they use print. ${ }^{78}$ Again, Farinosi, "[s]tudents ... feel that reading on screen creates a disconnection with the content and paper seems to allow readers to immerse themselves in the content better which improves learning." 79

\section{Outside FActors}

We consider these factors not only for the library, but for the student.

\section{Budget}

It was found that 86.9 percent of participants in Baron's study preferred print for academic reading if the cost to them was the same. ${ }^{80}$ A student from Mizachi's study claims "[i]f they were the same cost I would prefer the paper version..." 81

Law book prices have risen steeply over the past decades. In 1998 the annual cost for an average reporter was $\$ 856.21 .82$ By 2014, the cost was $\$ 9,121.18 .^{83}$ Law library budgets have been flat or declined over the same time period. ${ }^{84}$ Law libraries responded by cutting print collections, as early as $2008 .{ }^{85}$ For instance, Yale answered the price increases by cancelling almost all of the print reporters before $2012 .{ }^{86}$

Meanwhile, academic libraries generally have both Westlaw and LexisNexis, and present these tools to students at no additional cost. ${ }^{87}$ In contrast, eBook costs generally fall directly on students, as few law libraries pay for patron access to eBooks. ${ }^{88}$ Electronic aids are sometimes paid for by the library, but not generally. ${ }^{89}$

\section{Space}

Students report in Baron's study a preference for the convenience of storing books digitally. 90 "[E]lectronic textbooks means I do not have to carry it," a participant in Mizarchi's study notes. ${ }^{91}$ Farinosi's study disagrees,

${ }^{75}$ Ibid. at 598 .

${ }^{76}$ Lee A. Cummings et al., Comparing Electronic vs Print Book Preferences Between Students in the Social Sciences, the Arts and STEM, 32:4 LiBr. Hi TeCH News, 1 , 4 (2015).

${ }^{77}$ Ibid.

${ }^{78} \mathrm{Ji}$, supra note 6 , at 23.

${ }^{79}$ Farinosi, supra note 41 , at 418.

${ }^{80}$ Baron, supra note 10 , at 595.

${ }^{81}$ Mizrachi, supra note 24, at 302.

${ }^{82}$ Wilhelmina Randtke \& Stacy Fowler, The Current State of E-Books in U.S. Law Libraries: A Survey, 108 Law LiBr. J. 361, 363, 2016 LAW LiBR. J. 18 ๆ 23.

${ }^{83}$ Ibid. at 363, Table 1.

${ }^{84}$ Michael Whiteman, Book Burning in the Twenty-First Century: ABA Standard 606 and the Future of Academic Law Libraries as the Smoke Clears, 106 Law LiBr. J. 11, 20, 2014 Law LiBr. J. 2 \ 30.

${ }^{85}$ Amanda M. Runyon, The Effect of Economics and Electronic Resources on the Traditional Law Library Print Collection, 101 Law Libr. J. 177,185, 2009 Law Libr. J. 11 ๆ 24.

${ }^{86}$ Julian Aiken et al., Not Your Parents' Law Library: A Tale of Two Academic Law Libraries 16 GreEn BAg 2D 13, 15 (2012).

${ }^{87}$ Randtke, supra note 81 , at 370 वा 23.

${ }^{88}$ Ibid. at 932 .

${ }^{89}$ Ibid. at 934.

90 Baron, supra note 10 , at 592.

${ }^{91}$ Mizrachi, supra note 24, at 307. 
finding that print is easier physically because it isn't tied to power or location, you can pick it up and take it anywhere to use..$^{92}$

\section{Considering Audiences}

As we move toward conclusion, it is important to note the difference in audiences. My Dean was asked a question by a large law firm partner. Certainly the day-to-day needs of a partner are different than the average law student.

For instance, lawyers need to research under certain circumstances that force a large digest of information on tight deadlines. ${ }^{93}$ Studies have shown that lawyers create something akin to a precedent map in their minds as they work. ${ }^{94}$ This differs from the general needs of law students who have a prepared reading list at the beginning of the semester and work systematically on deep understanding of those readings.

A student working outside doctrinal courses is still likely to have more time than a practicing attorney. Chancellor notes that lawyers "prefer to receive their information within thirty minutes." 95 For a student writing a brief, paper, or even performing a research exercise, hours, days, weeks, or even months of time are given for completion.

And even after we consider these differences, it has been asserted many times that law students don't have the skills necessary for basic law practice. ${ }^{96}$ Noting we certainly need the tools practicing lawyers are using, we can also extrapolate that if the skills students gain in studying for doctrinal courses do not prepare them for practical legal research, we can safely conclude that practicing attorneys need different resources than students (at least insofar as their needs for doctrinal courses.)

\section{TeChNOlOgy GaPS}

One of the clearest advantages of electronic material is the speed with which it can be accessed. However, a law firm librarian described sending and resending a link to a material that continued to expire while the lawyer who needed the material tried to find time to access it. ${ }^{97}$ This demonstrates that mode of electronic delivery is an important factor when considering the possible advantages of electronic media.

Studies also show clear advantages to devices that use reflecting light not emitting light. ${ }^{98}$ Since studies show students generally use laptops when reading digital media, perhaps librarians should nudge students towards screens that do not use LCD.

\section{Conclusion}

Almost 150 years ago a sales man thought American case law should be indexed differently. ${ }^{99}$ That man, John West, created what has morphed into Westlaw. ${ }^{100}$ The Ohio Bar Association thought the cases and codes they needed should be online, Lexis endorsed that, and now entire categories of legal research are almost always performed online. ${ }^{101}$ Firms facing budget and space issues are discarding their print collections. ${ }^{102}$

${ }_{92}$ Farinosi, supra note 41 , at 417.

${ }^{93}$ Renate Chancellor, Getting It From the Source: What Librarians Think About Lawyer Search Behavior, 107 Law Libr. J. 287, 288, 2015 Law Libr. J. 12 q 2.

${ }^{94}$ Stuart A. Sutton, The Role of Attorney Mental Models of Law in Case Relevance Determinations: An Exploratory Analysis, 45 J. Am. Soc’y Info. ScI. 188, 192 (1994).

${ }_{95}$ Chancellor, supra note 92 , at 295 ๆ 22.

${ }^{96}$ See, e.g., Donald J. Dunn, Why Legal Research Skills Declined, or When Two Rights Make a Wrong, 85 Law LiBR. J. 49 (1993).

${ }^{97}$ Randtke, supra note 81 , at 61.

${ }^{98}$ Mangen, supra note 29, at 66.

99 Taryn Marks, John West and the Future of Legal Subscription Databases, 107 Law LiBR. J. 377, 377, 2015 Law Libr.

J. 18 ฯ1.

${ }^{100}$ Marks, supra note 69, at 84 \3.

${ }^{101}$ Marks, supra note 98 , at 384 ๆ 21.

${ }^{102}$ McQueen, supra note 7, at 66. 
As academic law librarians wait for word shift in ABA guidance as to if and how much print we have to keep, we all seek answers to the same questions. Do we have books? Yes, most of us will probably have books. How many? I'm not sure that is a metric worth pursuing. As Whiteman says, "one size does not fit all." 103 Surely there will always be giant print collections, but they also will certainly become less frequent as new buildings are built, libraries continue to invest in collaborative holdings, and the legal market continues to change. It seems a better practice to truly consider the needs of our individual programs of scholarship and education and make our own decisions accordingly. Below are my recommendations.

\section{Primary Sources}

Primary resources are not needed in print and should only be kept in certain, specific circumstances. Most current primary sources are held digitally for free by the government sources that produce them. ${ }^{104}$ They are also held in many fee-based digital platforms. ${ }^{105}$ LIPA and NELLCO have created a pilot project called PalmPrint to create a shared print repository of U.S. primary sources. ${ }^{106}$

The pros of digital format shine with primary sources. Premium discovery is key as the sheer amount of sources soar. Most of these materials do not require lengthy reading times or a particularly deep information processing strategy. When they do, they are often available for instant download in PDF. For instance, Westlaw provides almost all of their West Reporter cases in PDF images. ${ }^{107}$ Even those that aren't available this way can be downloaded or printed to PDF in dual column format that mimics the traditional print format. ${ }^{108}$

\section{Secondary Sources}

If possible, good secondary sources should be kept in both highly discoverable electronic format and easily arranged print. Discovery of electronic treatises can be tricky, making them less effective. Law libraries don't always include these titles in their catalogs, because they have to create or pay for catalog records and may have limited remedy if the resource link breaks or becomes outdated. ${ }^{109}$ Within popular electronic databases, treatises are now shown in search results alongside other materials, with no indication of their value or importance. ${ }^{110}$

It is also easy to consider how using a treatise online would be more impacted by scrolling or clicking issues. The Porion study found that participants who could flip through a text moved more quickly from page to page, while carrying a smaller cognitive load. ${ }^{11}$ Meaning the reader would spend so much energy navigating the treatise, they would not have as many resources remaining to digest the material.

Shelf browsing and tradition classification are valued tools of librarians, but perhaps are not compelling for students. ${ }^{112}$ While I personally feel adrift in the casual display at large bookstores, obviously the arrangement is working from a sales model.

103 Whiteman, supra note 83, at 26 - 47.

104 Whiteman, supra note 83, at 29 ๆ 55.

105 Ibid.

106 PALMPrint, http://www.nellco.org/?page=palmprint. It is worth noting that in a recent casual poll of Texas Law Libraries, the majority of directors declined to investigate pooling resources in the University of Texas/Texas A\&M Joint Library Facility. This was most commonly attributed to currently have the facility to store them. Amanda Watson, e-mail A\&M/UT Joint Library Facility (on file with author).

107 Thomson Reuters, West Reporter Images, https://lawschool.westlaw.com/marketing/display/SO/18.

108 Thomson Reuters, Welcome to WestlawNext: Introducing the Basics WORD, https://legalsolutions.thomsonreuters.com/ law-products/c/Welcome-to-WestlawNext-Introducing-the-Basics-WORD/p/990001250?trkcode=recspdpb\&trktype=internal\& FindMethod=recs.

109 Randtke, supra note 81, at 377 甲 67.

${ }^{110}$ Peter W. Martin, Possible Futures for the Legal Treatise in an Environment of Wikis, Blogs, and Myriad Online Primary

Law Sources, 108 Law Libr. J., 7, 21, 2016 Law Libr. J. 1 ๆ 33.

111 Porion, supra note 26, at 570.

112 Pat Parker, Automated Retrieval System Affects Legal Research: Is the Browsing Collection a Thing of the Past?, 7 Aall Spectrum 24, 25 (April 2003). Geoffrey C. Bowker \& Susan Leigh Starr, Sorting Things Out: Classification and Its Consequences 7 (2000). 
In discovery, arrangement, and delivery, treatises should be given prominence and "sold" to our students. Once found, they should be easily available in print (by traditional means or otherwise) to enable students the best chance for deep understanding, while minimizing eyestrain and time to read.

\section{Textbooks and Study Aids}

Textbooks and study aids should be available in print for students. Research has shown that e-textbook sales have not met pace with other eBook sales. ${ }^{113}$ The needs to annotate, and have deep understanding while avoiding eyestrain, pull for print. Discovery isn't much of an issue since textbooks are assigned and preferred study aids aren't voluminous in number. Delivery doesn't pose significant issues because need is well known and expected.

Should law libraries be in the business of providing text books and study aids in print? A review of top USNWR law libraries shows it is common for libraries to invest in study aids for students. Text books are a more split proposition. Some libraries specifically do not acquire textbooks. ${ }^{114}$ As a practice, I have never encouraged purchasing textbooks. It is problematic because of expense, timeliness, and the difficulty in providing them in the right way and amount. However, the research supporting this article has caused me to ask for a study from our acquisitions and access teams as to the cost and methods of such an undertaking.

\section{Answers}

Clearly, technological advancements will continue to improve, and the findings here will change along with those advancements. I can easily imagine a virtual reality system where students can have the benefits of print with the ease of electronic discovery and delivery elaborate. But we aren't there yet. And frankly, we can't know what exactly the next decade will hold.

As law schools build new buildings, many academic law librarians perhaps find themselves evaluating their print collections in a different way as they are asked to scrutinize every square foot assigned to the library.

I believe law librarians should do what they can to innovate within their own collections and services now, to collaborate with their colleagues and be ready to change as technologies become available. I do not think we should discard our print collections only because we assume they won't be needed in the future. "You can never plan the future by the past." 115

"Why do we have all these books?" Well, frankly, some we have because we have the space available to store them. If we don't have that space, we won't store them. Some we have because we have some sense of duty to collect certain materials in our jurisdiction and specialty areas. In the future, unless chosen as a repository for those collections, we won't store them. But some we have and will continue to have because they are an environmentally sustainable way to advance our mission of legal education and better serve our students. We have them because we think our students should read them.

${ }^{113}$ National Associate of College Bookstores, Update: Electronic Book and eReader Device Report March 2011, http:// www.nacs.org/LinkClick.aspx\%3Ffileticket\%3DuIf2NoXApKQ\%253D\%26tabid\%3D2471\%26mid\%3D3210.

${ }^{114}$ See, e.g., University of Cincinnati Libraries, Law Student Guide to the Law Library, http://guides.libraries.uc.edu/c.php? $\mathrm{g}=222405 \& \mathrm{p}=1474094$.

115 Edmund Burke, Letter to a Member of the National Assembly (1791). 